\title{
Collection, description and transfer of embryos from cattle 10-16 days after oestrus
}

\author{
K. J. Betteridge, M. D. Eaglesome, G. C. B. Randall and D. Mitchell \\ Animal Pathology Directorate, Health of Animals Branch, Agriculture Canada, \\ Animal Diseases Research Institute, P.O. Box 11300, Station H, Ottawa K2H 8P9, Canada
}

\begin{abstract}
Summary. Of 226 donor cattle treated with PMSG to induce superovulation, $76 \cdot 5 \%$ responded with 3 or more ovulations. Flushing at surgery or slaughter 10-16 days after oestrus recovered eggs and embryos that represented $49.3 \%$ of the number of ovulations. Of those recovered, $73.3 \%$ were embryos, an average yield of 4.0 embryos/treated cow or 4.8 embryos/flushed cow. The location of eggs and embryos was determined in 65 of the donors. Embryos and unfertilized eggs $(6 \cdot 1 \%$ of those recovered) were occasionally found in the oviducts. Empty zonae pellucidae were also found in the uterus on all days. The lengths, or diameters, of embryos were extremely variable within days and within donors, but mean values indicated logarithmic growth between Days 10 and 16. Eighty-four synchronous ( \pm 1 day) recipients received single embryos, and 51 recipients twin embryos, by surgical transfer. Pregnancies were obtained in recipients up to Day 16 but not on Day 17, indicating the stage by which an embryo must be present to prevent luteolysis. The overall pregnancy rate at Day 42 was $50.4 \%$ and a further $18.1 \%$ of the recipients exhibited extended oestrous cycles. Of 35 recipients that were allowed to go to term, 12 lost their pregnancies, most often between Days 42 and 63 .
\end{abstract}

\section{Introduction}

Most embryo transfers in cattle have been made about 1 week after oestrus when embryos are at the blastocyst stage and still within the zona pellucida. There are only a few reports on the collection and transfer of older, hatched embryos (Wilmut \& Rowson, 1973; Ayalon, Krieger \& Lewis, 1976; Renard, Heyman \& du Mesnil du Buisson, 1977; Heyman, Renard, Ozil \& du Mesnil du Buisson, 1978; Brand, Aarts, Zaayer \& Oxender, 1978a; Ozil, Heyman \& Renard, 1979), although thorough analogous studies have been made in sheep (Moor \& Rowson, 1966; Peterson, Tervit, Fairclough, Havik \& Smith, 1976).

This paper describes the collection of bovine embryos between Days 10 and 16 after oestrus (Day 0) and their transfer to recipients between Days 10 and 17. Part of the work has been briefly reported previously (Betteridge, Mitchell, Eaglesome \& Randall, 1976) and many of the embryos collected were used in concurrent sexing studies (see Hare et al., 1978).

\section{Materials and Methods}

Animals. Over a 5-year period 244 animals were used as donors and/or recipients. Apart from 4 animals reused as donors after calving, all were heifers, mostly (214) of dairy breeds. Donors were used up to 4 times and recipients once or twice. They had access to the outside except for 
the period of about 4 weeks before and after surgery and, in some cases, throughout pregnancy. Hay and concentrates were fed during the winter and to supplement summer grazing as necessary. Oestrus was detected and recorded twice daily by experienced herdsmen.

Superovulation and insemination. Superovulation and oestrus were induced in 226 potential donors: 214 animals received a single i.m. injection of 1666 or 2000 i.u. PMSG (Equinex: Ayerst Laboratories, Montreal) between Days 6 and 14 of the oestrous cycle, followed $40-44 \mathrm{~h}$ later by a single i.m. injection of a prostaglandin ( 25 or $30 \mathrm{mg}$ PGF-2 $\alpha$ : Upjohn; $100 \mathrm{mg}$ analogue AY 24655: Ayerst; or $500 \mu \mathrm{g}$ cloprostenol (Estrumate): Imperial Chemical Industries Ltd), and 12 donors received PMSG only (Betteridge \& Mitchell, 1974). Donors were inseminated naturally or artificially (with fresh or frozen semen) on the first day of the ensuing oestrus and again the following day when AI was used, or if the animals would stand for the bull.

Embryo collection. Embryos were collected aseptically from responding donors at surgery (94 donors) or slaughter (97 donors) on Days 10-16. The techniques for anaesthesia, surgical exposure of the reproductive tract, pre- and post-operative care, and collection of tracts from slaughtered animals were as described previously (Betteridge \& Mitchell, 1974). For flushing, a Foley catheter (18 French gauge) was inserted through a puncture made with closed artery forceps near the base of each uterine horn. The cuff was inflated and the horn flushed twice with $30 \mathrm{ml}$ medium towards the catheter from the ampulla of the oviduct or from the tip of the uterine horn. The flushings were collected into dishes which were usually round-bottomed but were flatbottomed for collections on Days 14-16 to prevent tangling of the longer embryos. For flushing similar embryos from slaughtered donors, the uterus was transected close to the cervix and held over the collecting dish. In 65 donors (1 at Day 10,2 at Day 11, 3 at Day 12, 17 at Day 13, 19 at Day 14, 15 at Day 15 and 8 at Day 16), oviducts and uterine horns were flushed separately to ascertain the location of the embryos and ova.

The flushing medium was either a supplemented Earle's-based Hepes-buffered tissue culture medium 199 (TCM-199, Gibco: Betteridge \& Mitchell, 1974; 125 donors), PB1 (Whittingham, 1971; 50 donors) or Dulbecco's phosphate-buffered saline, $\mathrm{pH} 7 \cdot 2$, supplemented with 1 or $2 \%$ bovine serum inactivated at $56^{\circ} \mathrm{C}$ for $30 \mathrm{~min}$ ( 8 donors). In 8 donors one horn was flushed with TCM-199, the other with PB1 to compare the effects of the two media on the embryos. Media were supplemented with the antibiotic neomycin sulphate $(200 \mu \mathrm{g} / \mathrm{ml})$.

Embryos and ova were recovered from the flushings under a dissecting microscope, transferred to fresh medium in $3.5 \mathrm{~cm}$ diameter disposable plastic Petri dishes and held at room temperature (about $23^{\circ} \mathrm{C}$ ) during more detailed examination with an inverted microscope. They were measured with a micrometer eyepiece or a rule.

Transfer of embryos. The 135 recipients used had been in oestrus synchronously with, or within 1 day of, their respective donors. The oestrus preceding transfer occurred spontaneously in 86 animals but had been induced in 49 animals by prostaglandin (PG) treatment 1 day before the PG treatment of the donors. Surgical transfer (flank and midline approaches) under general anaesthesia was used exclusively. There were 84 single transfers to the uterine horn ipsilateral to the corpus luteum and 51 twin transfers, one embryo being placed into each horn. Embryos were transferred as described previously (Betteridge \& Mitchell, 1974) using Pasteur pipettes up to $1.5 \mathrm{~mm}$ in diameter depending on embryo size. Transfers were made in TCM-199 except for 8 single and 13 twin transfers for which PB1 was used.

Recipients were observed for returns to oestrus and were examined for pregnancy by rectal palpation between Days 42 and 60. Extended cycles were defined as returns to oestrus after Day 24 in recipients with no history of long cycles and in which a palpable corpus luteum and/or elevated plasma progesterone levels (determined as by Betteridge, Sugden \& Eaglesome, 1977) provided supportive evidence of a prolonged luteal phase.

Of the pregnant recipients, 35 were kept until they calved or lost their pregnancies spontaneously. The others were induced to abort by administration of PG, used in other experimental work, or slaughtered. 
Differences in pregnancy rates between sub-groups were compared by using the $\chi^{2}$-test.

Most donors $(185 / 226)$ and recipients $(111 / 135)$ were bled at variable frequencies to provide plasma for concurrent studies.

\section{Results}

\section{Superovulation and embryo collection}

Of the 226 treated donors, 35 were not used because they failed to come into oestrus (13 animals) and/or ovulated $<3$ eggs (22 animals). The remaining 191 donors that were flushed (Table 1) included 11 animals with 1 , and 7 with 2 ovulations each. Thus 53 of the 226 donors (23.5\%) failed to respond adequately to the superovulatory treatment. The 908 embryos recovered represented an average of 4.0 /treated cow or $4 \cdot 8$ /flushed cow. At least 1 embryo was recovered from 148 donors $(77.5 \%$ of those flushed), $21(11.0 \%)$ yielded only unfertilized or degenerate ova and $22(11.5 \%)$ yielded neither embryos nor ova. Embryo and egg recovery rates at surgery and slaughter were similar.

Table 1. Overall rates of recovery of embryos and ova from 191 superovulated donors flushed at surgery or slaughter $10-16$ days after oestrus

\begin{tabular}{|c|c|c|c|c|c|c|c|c|}
\hline \multirow[b]{3}{*}{$\begin{array}{l}\text { Day of cycle at } \\
\text { recovery }\end{array}$} & \multirow[b]{3}{*}{ Method } & \multirow[b]{3}{*}{ Animals } & \multirow[b]{3}{*}{ Ovulations } & \multicolumn{5}{|c|}{ Ova and embryos recovered } \\
\hline & & & & \multicolumn{2}{|r|}{ Total } & \multicolumn{3}{|c|}{ Embryos } \\
\hline & & & & No. & $\begin{array}{c}\% \text { of } \\
\text { ovulations }\end{array}$ & No. & $\begin{array}{l}\% \text { of total } \\
\text { recovered }\end{array}$ & $\begin{array}{c}\text { \% of } \\
\text { ovulations }\end{array}$ \\
\hline 10 & $\begin{array}{l}\text { Surgery } \\
\text { Slaughter }\end{array}$ & $\begin{array}{r}10 \\
1\end{array}$ & $\begin{array}{r}101 \\
6\end{array}$ & $\begin{array}{r}44 \\
4\end{array}$ & $\begin{array}{l}43 \cdot 6 \\
66 \cdot 7\end{array}$ & $\begin{array}{r}31 \\
3\end{array}$ & $\begin{array}{l}70 \cdot 5 \\
75 \cdot 0\end{array}$ & $\begin{array}{l}30 \cdot 7 \\
50 \cdot 0\end{array}$ \\
\hline 11 & $\begin{array}{l}\text { Surgery } \\
\text { Slaughter }\end{array}$ & $\begin{array}{l}5 \\
1\end{array}$ & $\begin{array}{l}33 \\
14\end{array}$ & $\begin{array}{l}15 \\
12\end{array}$ & $\begin{array}{l}45 \cdot 5 \\
85 \cdot 7\end{array}$ & $\begin{array}{r}13 \\
0\end{array}$ & $\begin{array}{c}86 \cdot 7 \\
0\end{array}$ & $\begin{array}{c}39 \cdot 4 \\
0\end{array}$ \\
\hline 12 & $\begin{array}{l}\text { Surgery } \\
\text { Slaughter }\end{array}$ & $\begin{array}{l}7 \\
7\end{array}$ & $\begin{array}{l}89 \\
69\end{array}$ & $\begin{array}{l}52 \\
46\end{array}$ & $\begin{array}{l}58.4 \\
66 \cdot 7\end{array}$ & $\begin{array}{l}40 \\
29\end{array}$ & $\begin{array}{l}76.9 \\
63.0\end{array}$ & $\begin{array}{l}44.9 \\
42 \cdot 0\end{array}$ \\
\hline 13 & $\begin{array}{l}\text { Surgery } \\
\text { Slaughter }\end{array}$ & $\begin{array}{l}37 \\
37\end{array}$ & $\begin{array}{l}488 \\
541\end{array}$ & $\begin{array}{l}308 \\
241\end{array}$ & $\begin{array}{l}63 \cdot 1 \\
44 \cdot 5\end{array}$ & $\begin{array}{l}243 \\
185\end{array}$ & $\begin{array}{l}78 \cdot 9 \\
76 \cdot 8\end{array}$ & $\begin{array}{l}49.8 \\
34.2\end{array}$ \\
\hline 14 & $\begin{array}{l}\text { Surgery } \\
\text { Slaughter }\end{array}$ & $\begin{array}{l}14 \\
28\end{array}$ & $\begin{array}{l}205 \\
303\end{array}$ & $\begin{array}{r}79 \\
179\end{array}$ & $\begin{array}{l}38 \cdot 5 \\
59 \cdot 1\end{array}$ & $\begin{array}{r}67 \\
113\end{array}$ & $\begin{array}{l}84 \cdot 8 \\
63 \cdot 1\end{array}$ & $\begin{array}{l}32 \cdot 7 \\
37 \cdot 3\end{array}$ \\
\hline 15 & $\begin{array}{l}\text { Surgery } \\
\text { Slaughter }\end{array}$ & $\begin{array}{l}14 \\
16\end{array}$ & $\begin{array}{l}217 \\
215\end{array}$ & $\begin{array}{r}83 \\
103\end{array}$ & $\begin{array}{l}38.2 \\
47.9\end{array}$ & $\begin{array}{l}75 \\
66\end{array}$ & $\begin{array}{l}90 \cdot 4 \\
64 \cdot 1\end{array}$ & $\begin{array}{l}34 \cdot 6 \\
30 \cdot 7\end{array}$ \\
\hline 16 & $\begin{array}{l}\text { Surgery } \\
\text { Slaughter }\end{array}$ & $\begin{array}{l}7 \\
7\end{array}$ & $\begin{array}{r}144 \\
84\end{array}$ & $\begin{array}{l}24 \\
48\end{array}$ & $\begin{array}{l}16 \cdot 7 \\
57 \cdot 1\end{array}$ & $\begin{array}{l}12 \\
31\end{array}$ & $\begin{array}{l}50 \cdot 0 \\
64 \cdot 6\end{array}$ & $\begin{array}{r}8 \cdot 3 \\
36 \cdot 9\end{array}$ \\
\hline All & $\begin{array}{l}\text { Surgery } \\
\text { Slaughter }\end{array}$ & $\begin{array}{l}94 \\
97\end{array}$ & $\begin{array}{l}1277 \\
1232\end{array}$ & $\begin{array}{l}605 \\
633\end{array}$ & $\begin{array}{l}47.4 \\
51.4\end{array}$ & $\begin{array}{l}481 \\
427\end{array}$ & $\begin{array}{l}79 \cdot 5 \\
67 \cdot 5\end{array}$ & $\begin{array}{l}37.7 \\
34 \cdot 7\end{array}$ \\
\hline Total & & 191 & 2509 & 1238 & $49 \cdot 3$ & 908 & $73 \cdot 3$ & $36 \cdot 2$ \\
\hline
\end{tabular}

\section{Embryo location, appearance and growth}

In addition to the embryos listed in Table 1, 15 Day-11 embryos were examined after nonsurgical recovery from 4 donors.

In the 65 donors in which the locations of the embryos and ova were determined, 3 embryos were found in the oviducts of 1 Day-13 animal and 4 newly hatched embryos and 6 ova were found in one oviduct on Day 16. In both animals, embryos were also recovered from the adjacent uterine horns. The remaining 232 embryos $(97.1 \%)$ were in the uterus. In the remaining 63 donors, 11 unfertilized ova were found in the oviducts of 5 animals: 6 ova in 1 donor 
on Day 14, 1 ovum each in 3 donors on Day 15 and 2 ova in 1 donor on Day 16. The 24 ova and embryos in the oviducts represented $6.1 \%$ of the total recovered from these donors.

Also additional to the embryos in Table $1,27(2.2 \%$ of 1238$)$ were classified as degenerate or extremely retarded and unhatched: 11 were from 9 donors on Day 13, 14 from 3 donors on Day 14 and 2 from 1 donor on Day 16.

Apparently normal, unhatched embryos were found in 1 donor on each of Days 10,11 and 13. Hatching embryos were found on Days 10 (3 donors, 7 embryos), 12 (1 embryo), 13 (2 donors, 3 embryos) and 15 ( 2 donors, 3 embryos). The remaining embryos were hatched. Empty zonae pellucidae were recovered from 1 Day-10, 1 Day-11, 3 Day-12, 7 Day-13, 4 Day-14 and 2 Day-16 donors. Unfertilized ova with an intact zona pellucida were found on all days. Fragments of zona were seen adhering to one apparently normal Day-13 embryo.

The lengths of elongated, or the greatest diameters of spheroidal, embryos $(\mathrm{N}=831)$ are depicted in Text-fig. 1. Diameters of additional Day-8 (all unhatched) and Day-9 ( 7 hatched and 5 unhatched) embryos are included to provide an indication of embryonic growth after Day 10. For comparative purposes, the lengths of embryos on Days 12, 15 and 16 from cattle that had

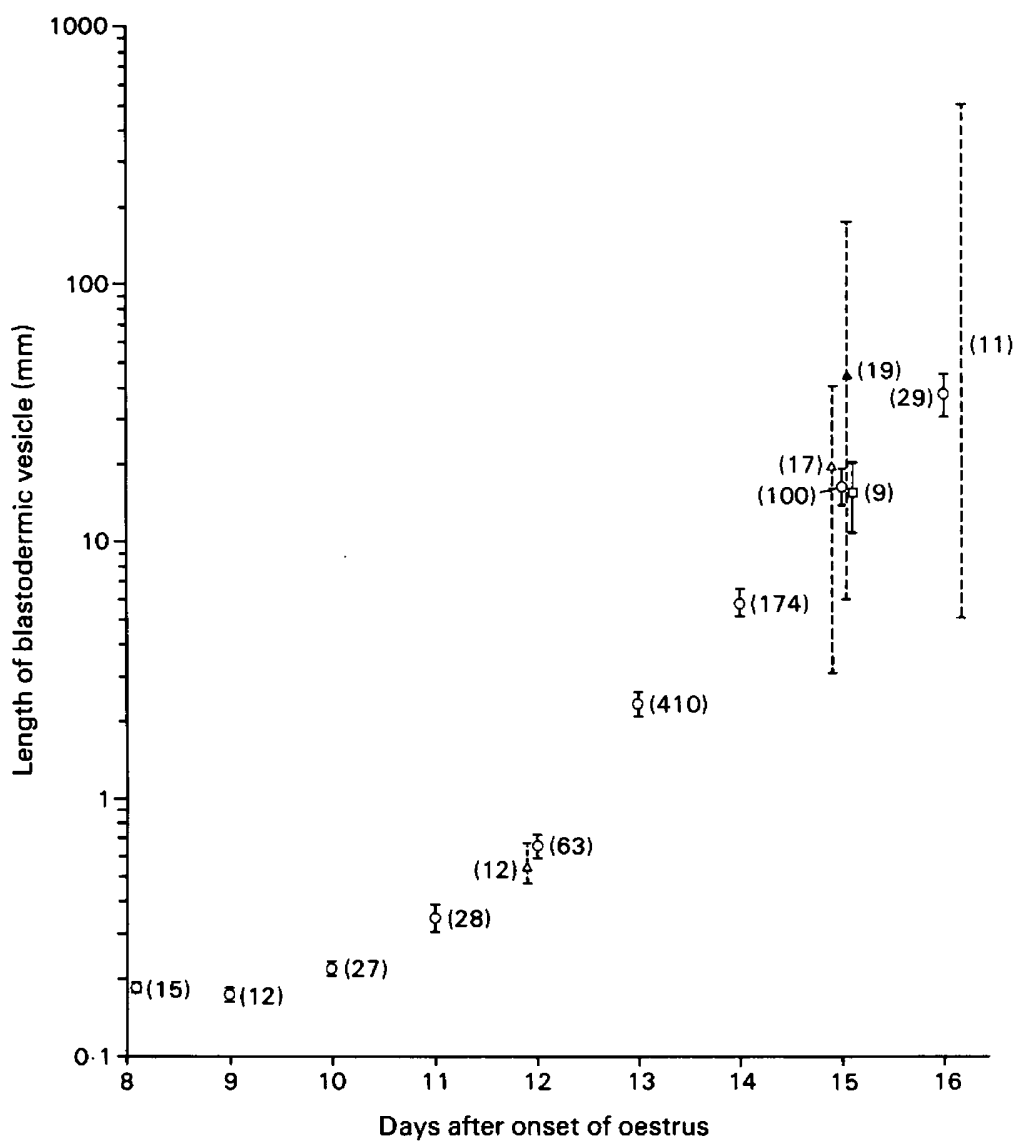

Text-fig. 1. The growth of embryos in cattle. Mean lengths are indicated on a logarithmic scale with the number of embryos for each point in parentheses for superovulating donors $(O$, with s.e.m. indicated by solid bars) and for non-superovulating cattle ( $\Delta$, data of $\mathbf{R}$. K. Christenson (unpublished) with range indicated by broken bars; $\square$, present data, with s.e.m. indicated by broken bars; Day-16 range, broken bars, from Boyd et al., 1969; $\Delta$, data of Staples, McEntee \& Hansel, 1961, with range indicated by broken bars). 
not been induced to superovulate are also shown. These were obtained from R. K. Christenson (personal communication, amplifying data in Christenson, Echternkamp \& Laster, 1975), from Boyd, Bacsich, Young \& McCracken (1969), from Staples et al. (1961) and from 9 untreated animals slaughtered during the present study.

Of the fetuses that survived to term or to the time of induced abortion or slaughter 52 could be identified as originating from measured embryos. The range of sizes of these 'proven survivors' is compared with overall size ranges in Table 2. Ten more embryos (1 Day-12, 4 Day13, 5 Day-15) that produced single fetuses after twin transfers were shown to have been within the same ranges as those tabulated for their respective days and another Day-16 survivor was either 17 or $25 \mathrm{~mm}$ long when transferred.

Table 2. Ranges of diameters or lengths of embryos recovered from cattle 10-16 days after oestrus

\begin{tabular}{cccccc}
\hline & \multicolumn{2}{c}{ All embryos } & & \multicolumn{2}{c}{ Proven survivors* } \\
\cline { 2 - 3 } \cline { 5 - 6 } Day & No. & Diameters or lengths $(\mu \mathrm{m})$ & & No. & Diameters or lengths $(\mu \mathrm{m})$ \\
\hline 10 & 27 & $90-307$ & 3 & $203-239$ \\
11 & 28 & $145-818$ & & - \\
12 & 63 & $145-2780$ & 15 & $261-1420$ \\
13 & 410 & $174-28000$ & 11 & $418-3090$ \\
14 & 174 & $226-57000$ & 14 & $610-40000$ \\
15 & 100 & $255-135000$ & 8 & $1795-18000$ \\
16 & 29 & $232-150000$ & 1 & 4000 \\
\hline All days & 831 & & 52 & \\
\hline
\end{tabular}

* See text.

\section{Embryo transfers}

Results obtained with the two media have been pooled because no difference could be detected between them in a direct comparison using twin transfers of Day-12 to Day-14 embryos (6/11 Day-42 pregnancies with PB1; 5/11 with TCM-199). Results of the 135 transfers are shown in Text-fig. 2. None of the Day-17 recipients was pregnant by Day 42 and so these 8 have been excluded from further analysis of pregnancy rates. Table 3 shows that pregnancy rates were higher with twin than with single transfers and higher with embryos obtained at surgery than with those from slaughtered donors. However, these differences were not significant $(P>0.05)$. In addition to the $50.4 \%$ recipients pregnant at Day 42 , a further $18 \cdot 1 \%$ (5/44 recipients of twins and $18 / 83$ recipients of single embryos) had extended oestrous cycles. Pregnancy rates were higher in PG-synchronized recipients $(27 / 46 ; 58.7 \%)$ than in naturally synchronous ones $(37 / 81 ; 45.7 \%)$ and higher in animals being used for the first time $(50 / 93 ; 53.8 \%)$ than in those undergoing a second operation $(14 / 34 ; 41.2 \%)$. However, these differences were not significant $(P>0.05)$.

Table 3. Day-42 pregnancy rates following surgical transfer of embryos to 10-16-day recipients that were synchronous ( \pm 1 day) with donors

\begin{tabular}{lccc}
\hline $\begin{array}{l}\text { Method of } \\
\text { collection }\end{array}$ & Twins & Singles & Totals \\
\hline Surgery & $10 / 15(66 \cdot 7 \%)$ & $26 / 49(53 \cdot 1 \%)$ & $36 / 64(56 \cdot 3 \%)$ \\
Slaughter & $16 / 29(55 \cdot 2 \%)$ & $12 / 34(35 \cdot 3 \%)$ & $28 / 63(44 \cdot 4 \%)$ \\
Totals & $26 / 44(59 \cdot 1 \%)$ & $38 / 83(45 \cdot 8 \%)$ & $64 / 127(50 \cdot 4 \%)$ \\
\hline
\end{tabular}




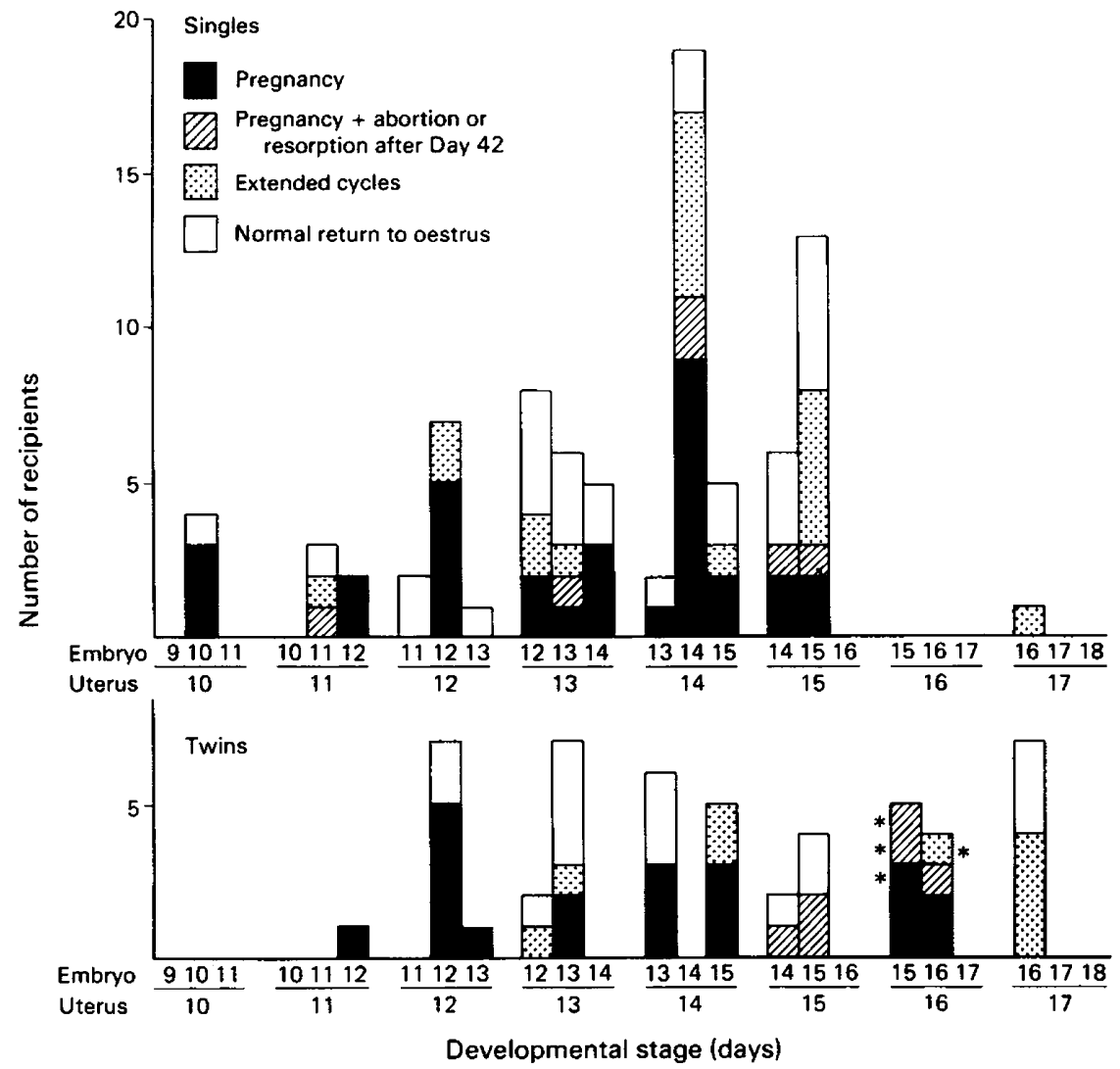

Text-fig. 2. Results of 84 single- and 81 twin-transfers in cattle 10-17 days after oestrus. Transfers for which one embryo may have been incomplete are indicated by an asterisk (*).

The time for which embryos were held in vitro pending transfer varied between 50 and 470 min. The slaughter-transfer interval averaged $229 \mathrm{~min}(\mathrm{~N}=92$; range $60-470 \mathrm{~min})$ overall, and $244 \mathrm{~min}(\mathrm{~N}=23$; range $60-430 \mathrm{~min})$ for proven survivors. The surgical flush-transfer interval averaged $144 \mathrm{~min}(\mathrm{~N}=79$; range $50-408 \mathrm{~min})$ overall and $151 \mathrm{~min}(\mathrm{~N}=29$; range $50-362$ $\mathrm{min}$ ) for proven survivors.

Of the 35 pregnant recipients that were being kept to term 12 lost their pregnancies (Table 4). Most of the early losses (7/10) occurred between Days 42 and 63, after palpation for pregnancy diagnosis, but one animal aborted at Day 50 without having been palpated. Twin calves or fetuses were produced by $6 / 14$ recipients that were kept to term and by $3 / 4$ recipients in which pregnancy was terminated earlier.

Table 4. Pregnancies lost after 42 days following surgical transfer of embryos to recipients at Days 10-16

\begin{tabular}{lcrcr}
\hline \multirow{2}{*}{$\begin{array}{c}\text { Embryos } \\
\text { transferred }\end{array}$} & $\begin{array}{c}\text { Pregnant } \\
\text { recipients }\end{array}$ & Days 42-94 & Days 253-258 & Total \\
\cline { 3 - 5 } & 19 & $5(26.3 \%)$ & $1(5.3 \%)$ & $6(31.6 \%)$ \\
Twins & 19 & $5(31.3 \%)$ & $1(6.3 \%)$ & $6(37.5 \%)$ \\
Singles & 16 & $10(28.6 \%)$ & $2(5.7 \%)$ & $12(34.3 \%)$ \\
Total & 35 & &
\end{tabular}


The proportion of embryos from a given donor that resulted in pregnancies following transfer varied: e.g. the embryos of 1 donor produced 8 pregnancies from transfers to 9 recipients, while those of another donor gave only one pregnancy after transfers to 8 recipients.

\section{Discussion}

The overall ovum and embryo recovery rate of $49 \%$ in flushed animals (Table 1) is low compared with the $72-73 \%$ achieved at Day 6 in large numbers of surgical recoveries (Marshall \& Struthers, 1978a, b) but is well within the ranges reported by others between Days 2 and 8 (see Elsden \& Betteridge, 1977, for review; Seidel, Elsden, Nelson \& Hasler, 1978). It is therefore impossible to differentiate between the respective influences of the later times of recovery and technical factors on recovery rates. Direct comparisons of recovery rates on various days after oestrus have shown a drop from Day 3 to Days 7 or 8 but not thereafter (Sreenan \& Beehan, 1976a; Newcomb \& Rowson, 1976; Brand, Trounson, Aarts, Drost \& Zaayer, 1978; Seidel, Elsden, Nelson \& Hasler, 1978). The satisfactory fertilization rate (73\% of those recovered) led to an average yield of $4.8 \mathrm{embryos} /$ flushed donor, lower than the extremely high rate of 11.9 embryos/flushed donor obtained in a series of 114 surgical recoveries by Marshall \& Struthers (1978b) but well within the range obtained between Days 2 and 8 by others (see review by Elsden \& Betteridge, 1977; Seidel et al., 1978; Boland, Crosby \& Gordon, 1978). The uterine environment resulting from the unusual endocrine status of superovulating donors is presumed to be responsible for the increase in the proportion of abnormal ova that occurs between Days 2 and 8 (see du Mesnil du Buisson, Renard \& Levasseur, 1977, for review; Boland et al., 1978). In the present study, ova classified as 'unfertilized' may have been fertilized and then degenerated in the longer intervals preceding collection. Good yields of embryos as late as Day 16 in this study and between Days 7 and 13 in other studies (see Renard et al., 1978) suggest that, at least until Day 16, the postulated uterine 'hostility' is not as important after Day 7 or 8 as before that time. This contention is supported by the fact that superovulating beef heifers that are not flushed do not lose their multiple pregnancies until some time between Days 16 and 45 (Henricks \& Hill, 1978).

Finding ova and embryos in the oviducts as late as Day 16 contrasts with the experience of Brand, Trounson, Aarts, Drost \& Zaayer (1978) who found none there in cows slaughtered between Days 7 and 12. Retention was not necessarily associated with blockage because ova and embryos had passed through the same tubes. The proportion retained $(6 \cdot 1 \%)$ is similar to the $7 \%$ found in oviducts on Days 6, 7 and 8 by Newcomb, Rowson \& Trounson (1976).

The most striking feature about the embryo sizes was the enormous variability encountered on any given day. This occurred even within donors (e.g. a size range of 4-40 mm from one Day-14 donor) and presumably is a result of collecting embryos which are at different stages of their logarithmic elongation growth phase. Similar variability was seen in a series of 31 Day-16 embryos from normally ovulating cows of low fertility (Hawk, Wiltbank, Kidder \& Casida, 1955): the mean length recorded $(95 \mathrm{~mm})$ was higher than in our series but the range of sizes (2$225 \mathrm{~mm}$ ) was comparable. Analogous findings have been reported for superovulating sheep (Rowson \& Moor, 1966). The narrower size range of 'proven survivors' should not be taken as evidence that those outside of this range were any less viable because the extremes of size were probably avoided in selecting embryos for transfer when recipient numbers were limited. However, the very long embryos (up to $15 \mathrm{~cm}$ ) cannot be considered ideal for transfer because of the mechanical difficulties of handling them. It seems likely that the smallest embryos seen during the later collection days were very retarded but in the absence of viability testing by transfer, or perhaps by biochemical means (Renard, Menezo, Saumande \& Heyman, 1978), this remains conjectural. In a much larger series of Day-10 embryos, Renard et al. (1978) encountered an even wider size range: $22 / 228$ embryos of healthy appearance had begun to elongate and had 
reached lengths of up to $625 \mu \mathrm{m}$. The mean diameter of 182 spherical blastocysts $(253 \mu \mathrm{m})$ was close to that seen in the present study $(222 \mu \mathrm{m})$ and the proportion of unhatched embryos amongst those looking healthy was also similar $(24 / 228$ or $10.5 \%$ compared with $4 / 34$ or $11.8 \%$ in our study).

The close similarity in the respective average sizes of Day-12 and Day-15 embryos from superovulating donors and from untreated cows contrasts with some sheep studies showing accelerated embryo growth from 8 days after superovulation (Wintenberger-Torrès, 1968). It also suggests that circulating, like luteal tissue, progesterone levels (Staples, McEntee \& Hansel, 1961) are not directly related to embryo size in cattle. This is of interest because, in sheep, progesterone has been considered to control the onset of the logarithmic phase of embryo growth at about Day 10 of normal pregnancy (Bindon, 1971b) and the considerable effects on embryo growth resulting from transfer of single embryos to superovulating recipients (Wintenberger-Torrès, 1968; Wintenberger-Torrès \& Rombauts, 1968) or from asynchronous transfers (Cahill \& Lawson, cited by Lawson, 1977). In rabbits, too, the adverse effects of asynchronous transfer are thought to involve progesterone levels either directly (Maurer \& Beier, 1976) or indirectly (Schacht \& Foote, 1978). However, comparison of separate reports suggests that the growth pattern of embryos in normal unstimulated sheep (Bindon, 1971a) resembles that seen in superovulating ewes (Rowson \& Moor, 1966).

Finding unfertilized and/or degenerate eggs with an intact zona pellucida, as well as zonae that have been shed, as late as Day 16 extends the observations of Hawk et al. (1955) and Ayalon, Weis \& Lewis (1968). This is analogous with the situation in sheep (Bindon, 1969, $1971 \mathrm{a}, \mathrm{b})$ and contrasts to the lysis of unfertilized eggs in the uterus by about Day 5 in mice (McLaren, 1969) and from Day 8 in rabbits (Adams, 1970). Although a distinction must be made between zona lysis and zona shedding (McLaren, 1969), this does suggest that, if zona lysins are involved in hatching in cattle and sheep, they are likely to be embryonic rather than uterine in origin. The relative importance of these two possible sources of zona lysins in laboratory animals is still contentious (Rosenfeld \& Joshi, 1977).

Transfer of 2 embryos into the non-pregnant uterus as late as 16 days after oestrus led to normal pregnancy. Even Day-17 transfers could prolong the luteal phase of recipients but no pregnancies were diagnosed among them at Day 42. Asynchrony of up to 1 day between donors and recipients did not appear to affect results but the effects of wider differences were not explored. Twin transfers were used in order to maximize the luteotrophic or antiluteolytic effects of the embros, so it is not known whether single transfer beyond Day 15 could lead to pregnancy. Cattle, like sheep (Moor \& Rowson, 1966; Peterson et al., 1976), embryos are therefore able to prevent luteolysis within a day or so of transfer. Embryo removal experiments have also confirmed that Day 16 is a critical stage in embryo-utero-ovarian relationships (Northey \& French, 1978). A full discussion of the means by which the Day-16 bovine embryo prevents luteolysis is beyond the scope of this paper but the likelihood that embryonic steroidogenesis and interaction between endometrial and trophoblastic tissues are involved has been reviewed (Heap, Flint, Gadsby \& Rice, 1979: see also Chenault, Laster \& Maurer, 1978; Shemesh, Milaguir, Ayalon \& Hansel, 1979). Day-16 embryos also evoke vascular changes that are probably responsible for the brief, localized increase in blood flow to the pregnant horn between Days 14 and 18 in cows (Ford, 1978; Ford, Chenault \& Echternkamp, 1979). The presence of placental lactogen in Day-17 bovine embryos is felt to be coincidental rather than direct evidence of an antiluteolytic role for that hormone (Flint, Henville \& Christie, 1979). Day-18 cattle embryos, like Day-13-15 sheep embryos, are directly luteotrophic in vitro (Hansel, Lukaszewska \& Beal, 1978; Godkin, Cote \& Duby, 1978) and differences in peripheral blood progesterone levels between pregnant and non-pregnant cattle as early as Days 6 or 8 suggest that luteotrophic effects may occur much earlier (Henricks, Dickey, Hill \& Johnston, 1972; Hansel et al., 1978). In sheep, however, Bindon (1971b) reported no such difference until Days 16-17.

Quantitative results such as rates of pregnancy, embryonic loss and extended oestrous cycles 
following transfer have to be interpreted cautiously in relatively small-scale experimental studies such as this for three main reasons. Firstly, a herd's natural fertility rate can vary from year to year and could be affected by undetected factors such as sub-clinical bovine virus diarrhoea (Archbald, Fulton, Seger, Al-Bagdadi \& Godke, 1979), a disease which is endemic in this area. Secondly, one or two donors whose embryos give exceptionally high or low pregnancy rates can exert a considerable influence in small groups of animals. Thirdly, experimental procedures such as frequent blood sampling may affect results. The unexplained declines in pregnancy rates in Day-10 to Day-16 recipients following twin and single transfers from $13 / 17(76 \cdot 5 \%)$ to $26 / 44$ $(59.1 \%)$ and from $36 / 75(48.0 \%)$ to $38 / 83(45.8 \%)$ respectively since the preliminary report of this work (Betteridge et al., 1976) exemplify the need for such caution. Using non-surgical techniques, pregnancy rates of $60.7 \%(17 / 28)$ have been obtained with Day-10 to Day-13 embryos (Heyman et al., 1978).

The $34.3 \%$ loss of pregnancies in 35 recipients after Day 42 is probably exaggerated by the exclusion of the 29 pregnant recipients that were slaughtered or induced to abort. The latter group had passed through the period of gestation when most losses occurred and those losses were later than losses reported for normally inseminated cattle (Ball, 1978: Ayalon, 1978). Nevertheless, the rate of loss is high and of interest. Rectal palpation is not considered to have been a major contibutor to the phenomenon in view of the experience of the examiner and other reports of low incidences of pregnancy failure after palpation (Paisley, Mickelson \& Frost, 1978). There are no reports of similar wastage following large-scale commercial transfer of younger embryos. Experimentally, Sreenan \& Beehan (1976b) found embryonic loss after Day 27 uncommon following surgical, bilateral twin transfers on Days 3-7 but Anderson, Cupps, Drost, Horton \& Wright (1978) recorded considerable losses (10/36, 28\%) up to Day 248 after one series of similar transfers though not after another (Schneider, 1978). Most of their losses (7/10) occurred later than Day 100. Non-surgical transfers seem prone to embryonic loss, especially between Days 45 and 90, whether the transfers are made by Day 9 (Hahn \& Hahn, 1976; Jillella \& Baker, 1978) or on Days 11-14 (Brand et al., 1978). The degree of loss seems to increase with the length of time that Day- 6 or -7 embryos are held in vitro before transfer (Hahn et al., 1978), suggesting that a variety of adverse influences on the younger embryo might prejudice its survival to term. The same may apply to older ones. In an additional experiment, run concurrently with the present study, $4 / 4$ recipients became pregnant following 3 twin and 1 single surgical transfers of Day-13 embryos that had been cultured for $20 \mathrm{~h}$ in Ham's F-10 medium with $10 \%$ heat-treated fetal calf serum under an atmosphere of $5 \% \mathrm{CO}_{2}: 5 \% \mathrm{O}_{2}: 90 \%$ air. One of the 4 died from an accident (strangulation) on Day 89 and her single fetus was considered small for its age; 2 aborted or resorbed their fetuses between Days 88 and 113; the 4th aborted twin fetuses on Day 143. In the main series of experiments, with transfers on the day of collection, no effect of time in vitro on embryo viability was evident and 1 calf was born from a Day-14 embryo that had been held for $7 \mathrm{~h} 10 \mathrm{~min}$.

Extended oestrous cycles have not been reported to be numerous following transfers of younger embryos except when 'adverse influences' such as freezing and thawing (Massip et al., 1978) or non-surgical transfer (Jillella, 1979) have been involved. Extension of the luteal phase probably reflects early death of the embryo after transfer (Betteridge, Eaglesome, Randall, Mitchell \& Sugden, 1978) and is thus comparable with the effects of early embryonic death detected by progesterone monitoring in cows (Ball, 1978; Kummerfeld, Oltenacu \& Foote, 1978 ) but which was rare $(<1 \%)$ in heifers in Ball's study.

Direct application of late embryo transfer to animal production is likely to be limited because of the reduced pregnancy rates, increased rates of embryonic loss and problems with low temperature preservation of older embryos (Trounson, Randall, Betteridge, Eaglesome \& Hare, 1978). It has proved useful when larger embryos are required, notably for sexing (Hare et al., 1978), but the development of reliable sexing procedures using earlier, freezable embryos (Moustafa, Hahn \& Roselius, 1978) might negate this requirement. However, late transfer may 
constitute a model system for inducing a high incidence of early embryonic loss. This, and the ability to collect, manipulate and transfer embryos at stages that are evidently critical in embryo-utero-ovarian interrelationships should be useful in studying both the physiology and pathology of early pregnancy.

We thank Mrs J. Hierlihy, Mrs S. Miller, Mr R. Bériault, Mr J. Shackleton, Mr G. Raby and $\mathrm{Mr}$ Y. Barbeau for technical assistance; and Miss E. Cathcart, Mr S. Shearer, Mr D. Mulvihill, Mr P. Gauthier and Mr G. Hogan for their care of the animals.

\section{References}

Adams, C.E. (1970) The fate of unfertilized eggs in the rabbit. J. Reprod. Fert. 23, 319-324.

Anderson, G.B., Cupps, P.T., Drost, M., Horton, M.B. \& Wright, R.W. (1978) Induction of twinning in beef heifers by bilateral embryo transfer. J. Anim. Sci. 46, 449-452.

Archbald, L.F., Fulton, R.W., Seger, C. L., Al-Bagdadi, F. \& Godke, R.A. (1979) Effects of the bovine viral diarrhea (BVD) virus on preimplantation bovine embryos: a preliminary study. Theriogenology 11,81-89.

Ayalon, N. (1978) A review of embryonic mortality in cattle. J. Reprod. Fert. 54, 483-493.

Ayalon, N., Weis, Y. \& Lewis, I. (1968) Fertility losses in normal cows and repeat breeders. Proc. 6th Int. Congr. Anim. Reprod. \& A. I., Paris, Vol. 1, pp. 393396.

Ayalon, N., Krieger, Y. \& Lewis, I. (1976) Non-surgical ova recovery of late blastocysts in cows. Proc. 8 th Int. Congr. Anim. Reprod. \& A. I., Krakow, Vol. 3, pp. 233-236.

Ball, P.J.H. (1978) The relationship of age and stage of gestation to the incidence of embryo death in dairy cattle. Res. vet. Sci. 25, 120-122.

Betteridge, K.J. \& Mitchell, D. (1974) Embryo transfer in cattle: experience of twenty-four completed cases. Theriogenology 1, 69-82.

Betteridge, K.J., Mitchell, D., Eaglesome, M.D. \& Randall, G.C.B. (1976) Embryo transfer in cattle 10-17 days after estrus. Proc. 8th Int. Congr. Anim. Reprod. \& A.I., Krakow, Vol. 3, pp. 237-240.

Betteridge, K.J., Sugden, E.A. \& Eaglesome, M.D. (1977) Synchronization of estrus and ovulation in cattle with prostaglandin analogue AY 24655. Can. J. Anim. Sci. 57, 23-32.

Betteridge, K.J., Eaglesome, M.D., Randall, G.C.B., Mitchell, D. \& Sugden, E.A. (1978) Maternal progesterone levels as evidence of luteotrophic or antiluteolytic effects of embryos transferred to heifers 12-17 days after estrus. Theriogenology 9, 86, Abstr.

Bindon, B.M. (1969) Fate of the unfertilized sheep ovum. J. Reprod. Fert. 20, 183-184.

Bindon, B.M. (1971a) Systematic study of preimplantation stages of pregnancy in the sheep. Aust. J. biol. Sci. 24, 131-147.

Bindon, B.M. (1971b) The role of progesterone in implantation in sheep. Aust. J. biol. Sci. 24, 149-158.

Boland, M.P., Crosby, T.F. \& Gordon, I. (1978) Morphological normality of cattle embryos following superovulation using PMSG. Theriogenology 10, $175-180$.
Boyd, H., Bacsich, P., Young, A. \& McCracken, J.A. (1969) Fertilization and embryonic survival in dairy cattle. Br. vet. J. 125, 87-97.

Brand, A., Aarts, M.H., Zaayer, D. \& Oxender, W.D. (1978) Recovery and transfer of embryos by nonsurgical procedures in lactating dairy cattle. In Control of Reproduction in the Cow, pp. 281291. Ed. J. M. Sreenan. Martinus Nijhoff, The Hague.

Brand, A., Trounson, A.O., Aarts, M.H., Drost, M. \& Zaayer, D. (1978) Superovulation and non-surgical embryo recovery in the lactating dairy cow. Anim. Prod. 26, 55-60.

Chenault, J.R., Laster, D.B. \& Maurer, R.R. (1978) Steroid metabolism by the preattached bovine conceptus. Proc. Am. Soc. Anim. Prod. (70th A. meeting, Michigan), Abstr. 340, p. 351.

Christenson, R.K., Echternkamp, S.E. \& Laster, D.B. (1975) Oestrus, LH, ovulation and fertility in beef heifers. J. Reprod. Fert. 43, 543-546.

du Mesnil du Buisson, F., Renard, J.-P. \& Levasseur, M.C. (1977) Factors influencing the quality of ova and embryos. In Embryo Transfer in Farm Animals: A Review of Techniques and Applications, Monograph No. 16, pp. 24-26. Ed. K. J. Betteridge. Agriculture Canada, Ottawa.

Elsden, R.P. \& Betteridge, K.J. (1977) Effects of different surgical collection methods on yield of ova. In Embryo Transfer in Farm Animals: A Review of Techniques and Applications, Monograph No. 16, pp. 14-16. Ed. K. J. Betteridge. Agriculture Canada, Ottawa.

Flint, A.P.F., Henville, A. \& Christie, W.B. (1979) Presence of placental lactogen in bovine conceptuses before attachment. J. Reprod. Fert. 56, 305-308.

Ford, S.P. (1978) Role of the early bovine conceptus and gravid uterus in altering uterine arterial contractility. J. Anim. Sci. 47, 538-543.

Ford, S.P., Chenault, J.R. \& Echternkamp, S.E. (1979) Uterine blood flow of cows during the oestrous cycle and early pregnancy: effect of the conceptus on the uterine blood supply. J. Reprod. Fert. 56, 53-62.

Godkin, J.D., Cote, C. \& Duby, R.T. (1978) Embryonic stimulation of ovine and bovine corpora lutea. $J$. Reprod. Fert. 54, 375-378.

Hahn, J. \& Hahn, R. (1976) Experiences with nonsurgical transfer techniques (and discussion). In $E g g$ Transfer in Cattle, pp. 199-207. Ed. L. E. A. Rowson. Commission of the European Communities, Luxembourg. 
Hahn, J., Moustafa, L.A., Schneider, U., Hahn, R. Romanowski, W. \& Roselius, R. (1978) Survival of cultured and transported bovine embryos following surgical and non-surgical transfers. In Control of Reproduction in the Cow, pp. 356-362. Ed. J. M. Sreenan. Martinus Nijhoff, The Hague.

Hansel, W., Lukaszewska, J. \& Beal, W. (1978) Maintenance of the bovine corpus luteum of early pregnancy. Biol. Reprod. 18, Suppl. 1, 27A, Abstr.

Hare, W.C.D., Singh, E.L., Betteridge, K.J., Eaglesome, M.D. Randal, G.C.B. \& Mitchell, D. (1978) Embryo sexing with particular reference to cattle. In Control of Reproduction in the Cow, pp. 441-449. Ed. J. M. Sreenan. Martinus Nijhoff, The Hague.

Hawk, H.W., Wiltbank, J.N., Kidder, H.E. \& Casida, L.E. (1955) Embryonic mortality between 16 and 34 days post-breeding in cows of low fertility. J. Dairy Sci. 38, 673-676.

Heap, R.B., Flint, A.P.F., Gadsby, J.E. \& Rice, C. (1979) Hormones, the early embryo and the uterine environment. J. Reprod. Fert. 55, 267-275.

Henricks, D.M. \& Hill, J.R. (1978) Effects of PMSG and $\mathrm{PGF}_{2 \alpha}$ on gonadal hormones and reproduction in the beef heifer.J. Anim. Sci. 46, 1309-1315.

Henricks, D.M., Dickey, J.F., Hill, J.R. \& Johnston, W.G. (1972) Plasma estrogen and progesterone levels after mating, and during late pregnancy and postpartum in cows. Endocrinology 90, 13361342.

Heyman, Y., Renard, J.-P., Ozil, J.-P. \& du Mesnil du Buisson, F. (1978) Cervical embryo transfer at different stages in cattle. In Control of Reproduction in the Cow, pp. 330-335. Ed. J. M. Sreenan. Martinus Nijhoff, The Hague.

Jillella, D. (1979) $A$ study of ovarian activity in the bovine with particular reference to superovulation and embryo transfer. Ph.D. thesis, University of Queensland.

Jillella, D. \& Baker, A.A. (1978) Transcervical transfer of bovine embryos. Vet. Rec. 103, 574-576.

Kummerfeld, H.L., Oltenacu, E.A.B. \& Foote, R.H. (1978) Embryonic mortality in dairy cows estimated by nonreturns to service, estrus, and cyclic milk progesterone patterns. J. Dairy Sci. 61, 1773-1777.

Lawson, R.A.S. (1977) Research applications of embryo transfer in sheep and goats. In Embryo Transfer in Farm Animals: A Review of Techniques and Applications, Monograph No. 16, pp. 72-78. Ed. K. J. Betteridge. Agriculture Canada, Ottawa.

McLaren, A. (1969) A note on the zona pellucida in mice. Adv. Reprod. Physiol. 4, 207-210.

Marshall, D.P.J. \& Struthers, G.A. (1978a) Commercial embryo-transfers in cattle. N.Z. vet.J. 26, 92-95.

Marshall, D.P.J. \& Struthers, G.A. (1978b) Commercial surgical embryo transfer in cattle. $N$. Z. vet. J. 26, 287-288.

Massip, A., Jacquelot, B., Ectors, F., Decoster, R., D'Ieteren, G., Hanzen, C. \& Derivaux, J. (1978) Congelation d'embryons suivie de transfert chez les bovins: premiere utilisation des paillettes. Annls Med. Vet. 122, 515-526.

Maurer, R.R. \& Beier, H.M. (1976) Uterine proteins and development in vitro of rabbit preimplantation embryos. J. Reprod. Fert. 48, 33-41.

Moor, R.M. \& Rowson, L.E.A. (1966) The corpus luteum of the sheep; functional relationships between the embryo and the corpus luteum. J. Endocr. 34, 233-239.

Moustafa, L.A., Hahn, J. \& Roselius, R. (1978) Versuche zur Geschlechtsbestimmung an Tag 6 und 7 alten Rinderembryonen. Berl. Münch. tierärztl. Wschr. 91, 236-238.

Newcomb, R. \& Rowson, L.E.A. (1976) Multiple ovulation, egg transplantation: towards twinning. In Principles of Cattle Production, pp. 59-83. Eds H. Swan \& W. H. Broster. Butterworths, London.

Newcomb, R., Rowson, L.E.A. \& Trounson, A.O. (1976) The entry of superovulated eggs into the uterus. In Egg Transfer in Cattle, pp. 1-15. Ed. L. E. A. Rowson, Commission of the European Communities, Luxembourg.

Northey, D.L. \& French, L.R. (1978) Effect of embryo removal on bovine interestrus interval. Proc. $\mathrm{Am}$. Soc. Anim. Prod. (70th A. Meeting, Michigan), Abstr. 412 , p. 380.

Ozil, J.-P., Heyman, Y. \& Renard, J.-P. (1979) An instrument for transcervical recovery of embryos from heifers. Theriogenology 11, 173-183.

Paisley, L.G., Mickelson, W.D. \& Frost, O.L. (1978) A survey of the incidence of prenatal mortality in cattle following pregnancy diagnosis by rectal palpation. Theriogenology 9, 481-491.

Peterson, A.J., Tervit, H.R., Fairclough, R.J., Havik, P.G. \& Smith, J.F. (1976) Jugular levels of 13,14dihydro-15-keto-prostaglandin $\mathrm{F}$ and progesterone around luteolysis and early pregnancy in the ewe. Prostaglandins 12, 551-558.

Renard, J.-P., Heyman, Y. \& du Mesnil du Buisson, F. (1977) Unilateral and bilateral cervical transfer embryos at the blastocyst stage. Theriogenology 7 , 189-194.

Renard, J.-P., Menezo, Y., Saumande, J. \& Heyman, Y. (1978) Attempts to predict the viability of cattle embryos produced by superovulation. In Control of Reproduction in the Cow, pp. 398-417. Ed. J. M. Sreenan. Martinus Nijhoff, The Hague.

Rosenfeld, M.G. \& Joshi, M.S. (1977) A possible role of a specific uterine fluid peptidase in implantation in the rat. J. Reprod. Fert. 51, 137-139.

Rowson, L.E.A. \& Moor, R.M. (1966) Development of the sheep conceptus during the first fourteen days. $J$. Anat. 100, 777-785.

Schacht, C.J. \& Foote, R.H. (1978) Progesteroneinduced asynchrony and embryo mortality in rabbits. Biol. Reprod. 19, 534-539.

Schneider, U. (1978) Discussion. In Control of Reproduction in the Cow, p. 313, Ed. J. M. Sreenan. Martinus Nijhoff, The Hague.

Seidel, G.E., Jr, Elsden, R.P., Nelson, L.D. \& Hasler, J.F. (1978) Methods of ovum recovery and factors affecting fertilisation of superovulated bovine ova In Control of Reproduction in the Cow, pp. 268-280. Ed. J. M. Sreenan. Martinus Nijhoff, The Hague.

Shemesh, M., Milaguir, F., Ayalon, N. \& Hansel, W. (1979) Steroidogenesis and prostaglandin synthesis by cultured bovine blastocysts. J. Reprod. Fert. 56, 181-185.

Sreenan, J.M. \& Beehan, D. (1976a) Methods of induction of superovulation in the cow and transfer results. In Egg Transfer in Cattle, pp. 19-34. Ed. L. E. A. Rowson. Commission of the European Communities, Luxembourg.

Downloaded from Bioscientifica.com at 04/26/2023 11:57:08AM 
Sreenan, J.M. Beehan, D. (1976b) Embryonic survival and development at various stages of gestation after bilateral egg transfer in the cow. J. Reprod. Fert. 47, 127-128.

Staples, R.E., McEntee, K. \& Hansel, W. (1961) Luteal function as related to pituitary and ovarian cytology and embryo development in the bovine. J. Dairy Sci. 44, 2049-2057.

Trounson, A.O., Randall, G.C.B., Betteridge, K.J., Eaglesome, M.D. \& Hare, W.C.D. (1978) Problems in freezing day 12 to 15 bovine embryos. Proc. Beltsville Symp. Agric. Res. III. Anim. Reprod., Abstr. 12.

Whittingham, D.G. (1971) Survival of mouse embryos after freezing and thawing. Nature, Lond. 233, 125126.

Wilmut, I. \& Rowson, L.E.A. (1973) Experiments on the low-temperature preservation of cow embryos. Vet. Rec. 92, 686-690.

Wintenberger-Torrès, S. (1968) Modification du milieu uterine chez les brebis superovulées et développement des blastocystes. Proc. 6th Int. Congr. Anim. Reprod. \& A.I., Paris, Vol. 1, pp. 491-494.

Wintenberger-Torrè, S. \& Rombauts, P. (1968) Relation entre la mortalité embryonnaire et la quantité de progesterone secrétée chez le brebis. Proc. 6th Int. Congr. Anim. Reprod. C.A.I., Paris, Vol 1, pp. 491-494.

Received 5 November 1979 